\title{
Mechanisms of Endothelial Cell ATP Depletion after Oxidant Injury ${ }^{1}$
}

\author{
SHARON P. ANDREOLI
}

Department of Pediatric Nephrology, Indiana University School of Medicine, Indianapolis, Indiana 46223

\begin{abstract}
To investigate mechanisms of ATP depletion in human umbilical vein endothelial cells after oxidant injury, we studied the relationship between DNA damage, activation of the DNA-repairing enzyme poly ADP-ribose polymerase, NAD depletion, and ATP depletion. We found that oxidant stress generated with hypoxanthine-xanthine oxidase and glucose-glucose oxidase resulted in profound DNA damage. When endothelial cells were exposed to 25 and $50 \mathrm{mU} / \mathrm{ml}$ xanthine oxidase for $60 \mathrm{~min}$, the percentage of double-stranded DNA was significantly reduced $(p<$ $0.05)$ to $15.2 \pm 1.2$ and $4.6 \pm 0.5 \%$, respectively, compared to $75.7 \pm 3.9 \%$ for control cells. When endothelial cells were exposed to 25 and $50 \mathrm{mU} / \mathrm{ml}$ glucose oxidase for $\mathbf{6 0}$ min, the percentage of double-stranded DNA was significantly $(p<0.05)$ reduced to $35.0 \pm 1.5 \%$ and $9.9 \pm 7.7 \%$, respectively, compared to $\mathbf{7 3 . 2} \pm \mathbf{2 . 4 \%}$ for control cells. ATP and NAD levels declined simultaneously with DNA damage. Because activation of the DNA-repairing enzyme poly ADP-ribose polymerase can consume NAD sufficient to interfere with ATP synthesis, we studied NAD and ATP levels after oxidant injury when ADP-ribose polymerase was inhibited with 3-aminobenzamide and nicotinamide. When poly ADP-ribose polymerase was inhibited, NAD levels remained normal, but ATP depletion was not prevented. We conclude that oxidant injury to human umbilical vein endothelial cells results in profound DNA damage and NAD and ATP depletion. NAD depletion results from activation of poly ADP-ribose polymerase, but this phenomenon is not the mechanism of ATP depletion in human umbilical vein endothelial cells. (Pediatr Res 25:97-101, 1988)
\end{abstract}

Abbreviations

FCS, fetal calf serum

HBSS + A, Hank's balanced salt solution with $0.5 \%$ albumin

NAD, nicotinamide adenine dinucleotide

SBTI, soybean trypsin inhibitor

PES, phenazine ethosulfate

During the past several years, research has focused on the role of oxidant injury in the pathophysiology of several human diseases. Tissue injury as a result of oxygen radical generation may

Received May 25, 1988; accepted September 14, 1988

Correspondence Sharon P. Andreoli, M.D., Department of Pediatric Nephrology, James Whitcomb Riley Hospital for Children, Indiana University Medical Center, One Children's Square, Indianapolis, IN 46223.

Supported by grants from the James Whitcomb Riley Memorial Association with funds contributed by the Mayflower Classic and the American Heart Association, Indiana Affiliate, with funds contributed by the Marion County Chapter.

'Presented in part at the American Society for Nephrology Annual Meeting December, 1986, Washington, DC, and at the Oxy-Radicals in Molecular Biology Meeting, January 1988, Park City, UT. be involved in the pathogenesis of inflammatory diseases, aging, carcinogenesis, and ischemia-reperfusion injury (1-3). The adult respiratory distress syndrome, emphysema, atherosclerosis, mycocardial infarction, glomerulonephritis, and rheumatoid arthritis are a few specific diseases in which oxidant stress is thought to play a role $(1-3)$. That oxidant stress has been implicated in the pathophysiology of several diseases suggests that reactive oxygen molecules may be the final common mediator of tissue injury after a number of diverse insults including metabolic, toxic, immunologic, and hypoxic.

The precise pathophysiologic mechanisms by which reactive oxygen molecules induce cellular injury are unknown. Oxygen radicals are capable of inducing damage to proteins through sulfhydryl oxidation, membranes via lipid peroxidation and nucleic acids by induction of DNA strand breaks $(3,4)$. After oxidant injury, several metabolic alterations occur, including activation of the glutathione-redox cycle, elevation of intracellular calcium, and depletion of cellular ATP stores (5-9). ATP levels decline as an early response to oxidant injury, whereas cell lysis indicated by ${ }^{51} \mathrm{Cr}$ release occurs considerably later (8). In lymphocytes and the P388D1 cell line, ATP depletion results from NAD depletion sufficient to interfere with ATP synthesis; NAD depletion is a result of activation of the DNA-repairing enzyme poly ADP-ribose polymerase, which consumes NAD $(10-12)$.

Because the endothelial cell is in close contact with polymorphonuclear leukocytes, monocytes, and mesangial cells that may each produce oxygen radicals when activated, the endothelial cell is at high risk for oxidant injury. In addition, because xanthine oxidase is primarily localized to capillary endothelial cells (13), the endothelium is at high risk for oxidant injury during reperfusion after ischemia. To investigate the mechanism responsible for the decline in endothelial cell ATP levels after oxidant injury, we measured NAD levels and DNA damage after oxidant injury with hypoxanthine-xanthine oxidase and glucose-glucose oxidase. In addition, we determined protection provided by 3aminobenzamide and nicotinamide, each inhibitors of poly ADP-ribose polymerase.

\section{METHODS}

Materials. The following materials were used in these studies: hypoxanthine, xanthine oxidase (grade I), glucose oxidase (type V), SBTI, Triton X-100, alcohol dehydrogenase, luciferin-luciferase, ATP, NAD, ethanol, catalase, perchloric acid, mesoinositol, urea, sodium dodecylsulfate, mercaptoethanol, ethidium bromide (Sigma Chemical Co., St. Louis, MO); N-bis-2hydroxyethyl-glycine sodium bicine, sodium iodoacetate, and thiazolyl blue (Calbiochem, San Diego, CA); normal human albumin (Armour Pharmaceutical Co., Kankakee, IL), M199, FCS, penicillin-streptomycin, HEPES buffer, HBSS, trypsin EDTA, (GIBCO, Grand Island, NY); collagenase (type II) (Worthington Diagnostic Systems, Inc., Freehold, NJ); PES (ICN Biochemicals, Cleveland, $\mathrm{OH}$ ); diaminocyclohexanetetraacetic acid (Aldrich Chemical Co., Milwaukee, WI). 
Endothelial cell cultures. Human endothelial cells were obtained from umbilical veins by collagenase digestion (6). The endothelial cells were incubated in M199 with 20\% pooled normal human serum, penicillin $(100 \mathrm{U} / \mathrm{ml})$, streptomycin $(100$ $\mu \mathrm{g} / \mathrm{ml}$ ) and $20 \mathrm{mM}$ HEPES buffer at $37^{\circ} \mathrm{C}$ in a humidified environment containing $5 \% \mathrm{CO}_{2}$ for 4-7 days until the cells were a confluent monolayer. Cells from at least 3 cords were then passed and plated onto 24-well Costar plates (Costar Data Packaging Corp., Cambridge, MA) at a density of approximately 50,000 cells $/ \mathrm{cm}^{2}$ in M199 containing $20 \% \mathrm{FCS}$, penicillin (100 $\mathrm{U} / \mathrm{ml})$, streptomycin $(100 \mu \mathrm{g} / \mathrm{ml})$, and $20 \mathrm{mM}$ HEPES buffer. After approximately 3 days, the cells were a confluent monolayer; at confluency, one well of a 24-well Costar plate contains approximately 200,000 cells. All experiments were performed with cells from the first or second passage. Cells were identified as endothelial by a cobblestone appearance with phase contrast microscopy and positive direct immunofluorescence for factor VIII-related antigen in more than $98 \%$ of the cells.

DNA damage. We determined DNA damage with the fluorometric technique used by Birnboim et al. (14) as adapted to endothelial cells by other investigators (15). This assay monitors the unwinding of DNA in alkaline solutions by measuring the fluorescence of ethidium bromide binding to residual doublestranded DNA. Endothelial cells in 24-well Costar plates were incubated with 0,25 , and $50 \mathrm{mU} / \mathrm{ml}$ glucose oxidase with 5.5 $\mathrm{mM}$ glucose and 0,25 , and $50 \mathrm{mU} / \mathrm{ml}$ xanthine oxidase with $5.0 \mathrm{mM}$ hypoxanthine and $5 \mathrm{mg} / \mathrm{ml}$ SBTI for $15,30,45$, and 60 min. The supernatant was aspirated, endothelial cells were removed with trypsin EDTA, cells from four replicate wells were pooled and were resuspended in $1 \mathrm{ml}$ of $0.25 \mathrm{M}$ meso-inositol, $10 \mathrm{mM}$ sodium phosphate, $1 \mathrm{mM} \mathrm{MgCl}_{2}, \mathrm{pH}$ 7.2. Samples consisting of $200 \mu \mathrm{l}$ were dispensed to four sets of test tubes. In one, alkaline unwinding was prevented (representing total double-stranded DNA); in another tube, the cells were sonicated to allow maximum unwinding to determine background fluorescence; in the two remaining tubes, unwinding was not altered. At the end of the alkaline incubation, $1.5 \mathrm{ml}$ of $6.7 \mu \mathrm{g} / \mathrm{ml}$ ethidium bromide in $13.3 \mathrm{mM} \mathrm{NaOH}$ was added and fluorescence was read in a Perkin-Elmer MPF 44B fluorescent spectrophotometer (Perkin-Elmer Corp. Instrument Div., Norwalk, CT) at an excitation wavelength of $520 \mathrm{~nm}$ and an emission wavelength of $590 \mathrm{~nm}$. The percentage of double-stranded DNA was calculated by (sample fluorescence - background fluorescence)/ (total fluorescence - background fluorescence) $\times 100$.

$A T P$ levels. Endothelial cells in 24-well Costar plates were incubated with 10,25 , and $50 \mathrm{mU} / \mathrm{ml}$ glucose oxidase with 5.5 $\mathrm{mM}$ glucose or 10,25 , and $50 \mathrm{mU} / \mathrm{ml}$ xanthine oxidase with 5.0 $\mathrm{mM}$ hypoxanthine with $5 \mathrm{mg} / \mathrm{ml} \mathrm{SBTI}$ in a final volume of 400 $\mu \mathrm{l} \mathrm{HBSS}+\mathrm{A}$ for 30,60 , and $90 \mathrm{~min}$. At the completion of experiments, endothelial cells were solubilized with $500 \mu \mathrm{l}$ of $0.5 \%$ Triton and acidified with $100 \mu \mathrm{l} 0.6 \mathrm{M}$ perchloric acid and placed on ice until assayed. At the time of assay, the endothelial cell suspension was diluted 1:800 with $10 \mathrm{mM}$ potassium phosphate buffer containing $4 \mathrm{mM} \mathrm{MgSO}_{4}(\mathrm{pH} \mathrm{7.4);} 500 \mu \mathrm{l}$ of this mixture was added to $1 \mathrm{ml}$ of $50 \mathrm{mM}$ sodium arsenate buffer containing $20 \mathrm{mM} \mathrm{MgSO}_{4}$ (pH 7.4) to which $25 \mu \mathrm{l}$ of $40 \mathrm{mg} / \mathrm{ml}$ luciferin-luciferase was added. Light emission was recorded precisely at $20 \mathrm{~s}$ with a Packard $\beta$ counter (Hewlett-Packard Co., Palo Alto, CA) accepting signals out of coincidence (16). ATP levels were expressed as $\mathrm{pmol} / \mu \mathrm{g}$ of protein. Protein content was determined on a portion of the cell sample by the method of Lowry with bovine serum albumin as the standard (17). To determine if reactive oxygen molecules caused direct degradation of ATP, glucose-glucose oxidase $(10,25$, and $50 \mathrm{mU} / \mathrm{ml})$ and hypoxanthine-xanthine oxidase $(10,25$, and $50 \mathrm{mU} / \mathrm{ml})$ were each incubated with ATP standard for $1 \mathrm{~h}$. To determine if ATP was in the extracellular fluid after oxidant injury, ATP levels were determined on supernants of cells exposed to 10,25 , and $50 \mathrm{mU} / \mathrm{ml}$ glucose oxidase and 10,25 , and $50 \mathrm{mU} / \mathrm{ml}$ xanthine oxidase for $60 \mathrm{~min}$.
$N A D$ levels. NAD levels were determined by an enzymatic cycling assay (18). Endothelial cells in 24-well Costar plates were incubated with 10,25 , and $50 \mathrm{mU} / \mathrm{ml}$ glucose oxidase with 5.5 $\mathrm{mM}$ glucose or 10,25 , and $50 \mathrm{mU} / \mathrm{ml}$ xanthine oxidase with 5.0 $\mathrm{mM}$ hypoxanthine with $5 \mathrm{mg} / \mathrm{ml} \mathrm{SBTI}$ for 30,60 , and $90 \mathrm{~min}$. At the completion of experiments, endothelial cells were solubilized with $500 \mu \mathrm{l}$ of $0.5 \%$ Triton, acidified with $100 \mu \mathrm{l}$ of $0.6 \mathrm{M}$ perchloric acid, neutralized with $\mathrm{KOH} ; 50 \mu \mathrm{l}$ of the sample were then added to $1.15 \mathrm{ml}$ of reaction mixture containing $120 \mu \mathrm{m}$ sodium bicine, $600 \mu \mathrm{m}$ ethanol, $2 \mu \mathrm{m}$ PES, and $0.5 \mu \mathrm{m}$ thiazolyl blue. The samples were incubated at $37^{\circ} \mathrm{C}$ for $60 \mathrm{~min}$ after the addition of $0.2 \mathrm{mg}$ alcohol dehydrogenase. The absorbance was measured at $570 \mathrm{~nm}$, the amount of NAD present was determined with a standard curve, and NAD levels were normalized to cell protein levels as for ATP.

Inhibition studies. To determine if NAD and ATP depletion is a result of activation of the enzyme poly ADP-ribose polymerase, ATP and NAD levels were determined after oxidant injury with and without two inhibitors of poly ADP-ribose polymerase, nicotinamide and 3-aminobenzamide. NAD and ATP levels were determined in endothelial cells exposed to $10,20,30,40$, and $50 \mathrm{mU} / \mathrm{ml}$ glucose oxidase with $5.5 \mathrm{mM}$ glucose for $60 \mathrm{~min}$ and $10,20,30,40$, and $50 \mathrm{mU} / \mathrm{ml}$ xanthine oxidase with 5.0 $\mathrm{mM}$ hypoxanthine for $60 \mathrm{~min}$ with no inhibitor, with $5.0 \mathrm{mM}$ or $10.0 \mathrm{mM}$ nicotinamide, and with $5.0 \mathrm{mM}$ 3-aminobenzamide.

Scavenger experiments. To determine which oxygen radical(s) mediates DNA damage, endothelial cell monolayers in 24-well plates were incubated for 60 min with $25 \mathrm{mU} / \mathrm{ml}$ xanthine oxidase and $5.0 \mathrm{mM}$ hypoxanthine with $5 \mathrm{mg} / \mathrm{ml} \mathrm{SBTI}$ or 25 $\mathrm{mU} / \mathrm{ml}$ glucose oxidase with $5.5 \mathrm{mM}$ glucose and either no scavenger or $100 \mu \mathrm{g} / \mathrm{ml}$ superoxide dismutase, $100 \mu \mathrm{g} / \mathrm{ml}$ catalase, $0.1 \%$ dimethylsulfoxide, or $75 \mu \mathrm{M}$ deferoxamine in a final volume of $400 \mu \mathrm{l}$ HBSS + A. After a 60 -min incubation, DNA damage was determined as previously described.

Statistical analysis. Data analysis was performed with Student $t$ test when comparing paired data. Data are presented as mean $\pm 1 \mathrm{SD}$.

\section{RESULTS}

$D N A$ damage. When endothelial cells were exposed to 25 and $50 \mathrm{mU} / \mathrm{ml}$ glucose oxidase for $60 \mathrm{~min}$, the percentage of doublestranded DNA was significantly $(p<0.05)$ reduced to $35.0 \pm$ 1.5 and $9.9 \pm 7.7 \%$, respectively, compared to $73.2 \pm 2.4 \%$ for control cells (Fig. 1A). When endothelial cells were exposed to 25 and $50 \mathrm{mU} / \mathrm{ml}$ xanthine oxidase for $60 \mathrm{~min}$, the percentage of double-stranded DNA was significantly $(p<0.05)$ reduced to $15.2 \pm 1.2$ and $4.6 \pm 0.5$, respectively, compared to $75.7 \pm 3.9 \%$ for control cells (Fig. $1 B$ ). Endothelial cells exposed to 25 and $50 \mathrm{mU} / \mathrm{ml}$ glucose oxidase with $5.5 \mathrm{mM}$ glucose or 25 and 50 $\mathrm{mU} / \mathrm{ml}$ xanthine oxidase with $5.0 \mathrm{mM}$ hypoxanthine for shorter periods of time also demonstrated DNA damage. When endothelial cells were incubated with 25 and $50 \mathrm{mU} / \mathrm{ml}$ glucose oxidase for $60 \mathrm{~min}$ in the presence of $100 \mu \mathrm{g} / \mathrm{ml}$ catalase, the percentage of double-stranded DNA $(70.0 \pm 2.0$ and $71.9 \pm$ $4.0 \%$, respectively) was similar to control cells.

Similar results were seen when endothelial cells were incubated with 25 and $50 \mathrm{mU} / \mathrm{ml}$ xanthine oxidase for $60 \mathrm{~min}$ in the presence of $100 \mu \mathrm{g} / \mathrm{ml}$ catalase; the percentage of doublestranded DNA $(73.7 \pm 3.5$ and $85.7 \pm 6.9 \%)$ was not significantly different from control cells $(75.7 \% \pm 3.9 \%)$. Thus, each oxygen radical-generating system produced DNA damage that was prevented by catalase. When cells from two other endothelial cohorts were damaged in an identical manner, very similar results were obtained. After a 60 -min exposure of $25 \mathrm{mU} / \mathrm{ml}$ glucose oxidase with $5.5 \mathrm{mM}$ glucose, the percentage of residual double-stranded DNA was $11.4 \pm 2.7 \%$ (compared to $81.5 \pm 6.0 \%$ for control cells) for one cohort and $8.63 \pm 9.4 \%$ (compared to $80.0 \pm 7.1 \%$ for control cells) for another cohort. After a 6-min exposure to $25 \mathrm{mU} / \mathrm{ml}$ xanthine oxidase with $5.0 \mathrm{mM}$ hypoxanthine, the 


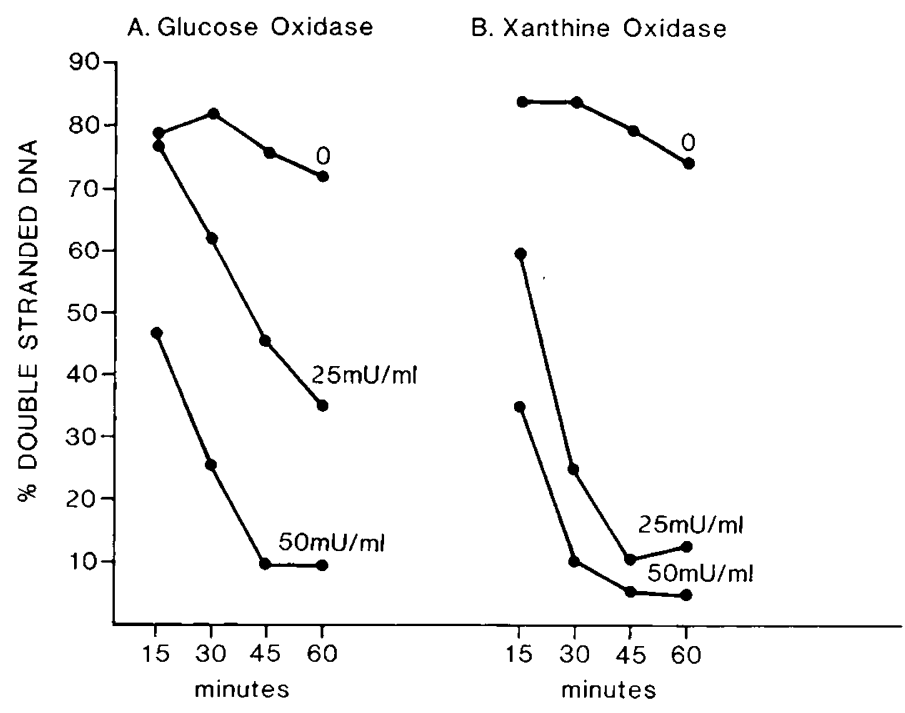

Fig. 1. Percentage of residual double-stranded DNA of endothelial cells incubated with 0,25 , and $50 \mathrm{mU} / \mathrm{ml}$ glucose oxidase with $5.5 \mathrm{mM}$ glucose for $15,30,45$, and $60 \mathrm{~min}(A)$ and percentage of residual doublestranded DNA of endothelial cells incubated with 0,25 , and $50 \mathrm{mU} / \mathrm{ml}$ xanthine oxidase with $5.0 \mathrm{mM}$ hypoxanthine and $5 \mathrm{mg} / \mathrm{ml} \mathrm{SBTI}$ for 15 , 30,45 , and $60 \mathrm{~min}$. DNA damage is apparent in each oxygen radicalgenerating system. Values represent the mean of two replicates.

percentage of residual double-stranded was $6.9 \pm 1.0 \%$ (compared to $74.0 \pm 3.7 \%$ for control cells) for one cohort and 12.2 $\pm 3.6 \%$ (compared to $79.1 \pm 6.3 \%$ for control cells) for another cohort.

$A T P$ and NAD levels. When endothelial cells were exposed to oxygen radicals generated by 10,25 , and $50 \mathrm{mU} / \mathrm{ml}$ glucose oxidase or 10,25 , and $50 \mathrm{mU} / \mathrm{ml}$ xanthine oxidase for 30,60 , and $90 \mathrm{~min}$, ATP levels declined (Fig. 2). The decrease in endothelial cell ATP levels was not the result of a direct effect of glucose oxidase, xanthine oxidase, or the oxygen products generated because there was more than $95 \%$ recovery of ATP standard incubated with 10,25 , and $50 \mathrm{mU} / \mathrm{ml}$ glucose oxidase with $5.5 \mathrm{mM}$ glucose and xanthine oxidase with $5.0 \mathrm{mM}$ hypoxanthine for $1 \mathrm{~h}$ (data not shown). The decline in ATP levels was not the result of direct release of ATP from the cell as ATP was not detected in supernatants when endothelial cells were exposed to 10,25 , and $50 \mathrm{mU} / \mathrm{ml}$ glucose oxidase or 10,25 , and $50 \mathrm{mU} / \mathrm{ml}$ xanthine oxidase for $60 \mathrm{~min}$ with or without inhibitors of poly ADP-ribose polymerase. When endothelial cells were exposed to 10,25 , and $50 \mathrm{mU} / \mathrm{ml}$ glucose oxidase for $60 \mathrm{~min}$, NAD levels fell to $1.00 \pm 0.13,0.25 \pm 0.08$, and $0.105 \pm 0.085$ $\mathrm{pmol} / \mu \mathrm{g}$ protein, respectively, compared to $1.24 \pm 0.16 \mathrm{pmol} /$ $\mu \mathrm{g}$ protein for control cells (Fig. 2). When endothelial cells were exposed to 10,25 , and $50 \mathrm{mU} / \mathrm{ml}$ xanthine oxidase for $60 \mathrm{~min}$, NAD levels fell to $1.06 \pm 0.06,0.50 \pm 0.02$, and $0.31 \pm 0.06$ $\mathrm{pmol} / \mu \mathrm{g}$ protein, respectively, compared to $1.30 \pm 0.24 \mathrm{pmol} /$ $\mu \mathrm{g}$ protein for control cells (Fig. 2). Thus, in each oxygen radical generating system, the NAD levels fell simultaneously with the decline in ATP levels (Fig. 2).

Inhibition studies. As shown in Table 1, ATP and NAD levels declined when endothelial cells were exposed to glucose-glucose oxidase and hypoxanthine-xanthine oxidase. When poly ADPribose polymerase was inhibited with $5.0 \mathrm{mM} 3$-aminobenzamide, NAD levels remained normal at each dose of glucose oxidase and xanthine oxidase. When poly ADP-ribose polymerase was inhibited with $5.0 \mathrm{mM}$ nicotinamide, NAD depletion was prevented. NAD levels remained normal at lower doses of glucose oxidase and xanthine oxidase and at higher doses, substantial protection of NAD levels was observed. When poly ADP-ribose polymerase was inhibited with 5.0 and $10.0 \mathrm{mM}$ nicotinamide

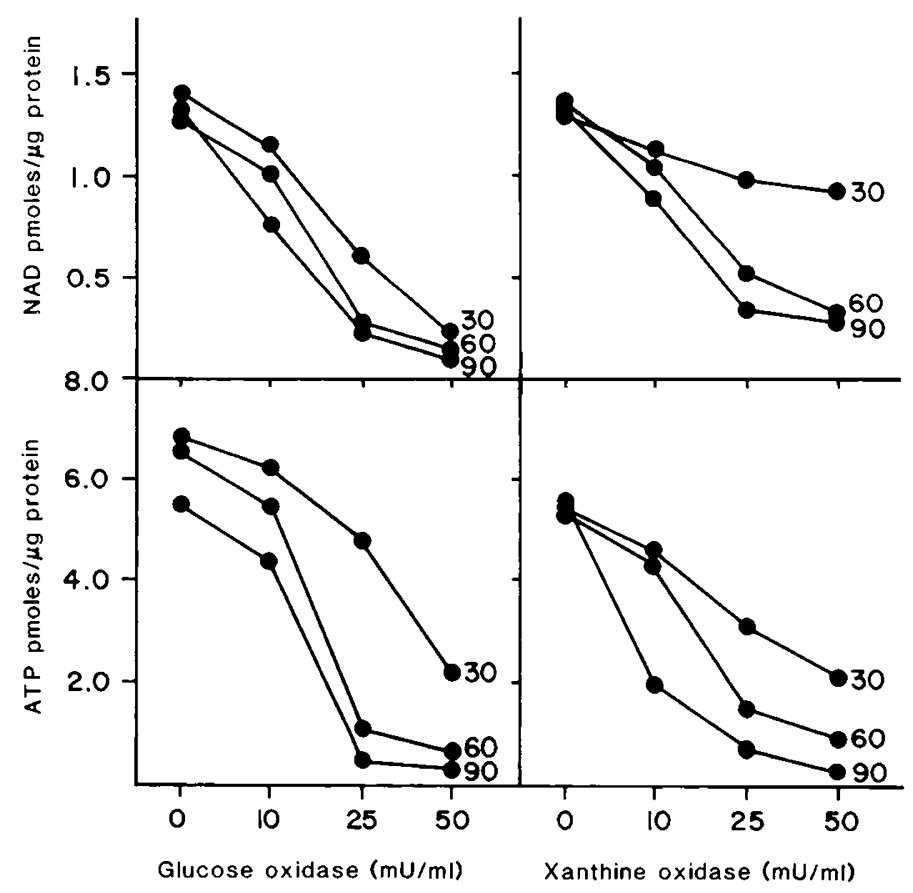

Fig. 2. Endothelial cell levels of NAD and ATP after exposure to 10 , 25 , or $50 \mathrm{mU} / \mathrm{ml}$ glucose oxidase with $5.5 \mathrm{mM}$ glucose for 30,60 , and $90 \mathrm{~min}$, and endothelial cell levels of NAD and ATP after exposure to 10,25 , or $50 \mathrm{mU} / \mathrm{ml}$ xanthine oxidase with $5.0 \mathrm{mM}$ hypoxanthine with $5 \mathrm{mg} / \mathrm{ml} \mathrm{SBTI}$ for 30,60 , and $90 \mathrm{~min}$. The NAD level fell simultaneously with the decline in ATP levels. Values represent the mean of two to four replicates.

in another endothelial cell cohort, $5.0 \mathrm{mM}$ nicotinamide again resulted in substantial protection from NAD depletion, whereas $10.0 \mathrm{mM}$ nicotinomide resulted in complete protection from NAD depletion. In contrast, ATP depletion was not prevented by inhibition of poly ADP-ribose polymerase in either oxygen radical-generating system. ATP was not detected in the endothelial cell supernatants in the presence or absence of $5.0 \mathrm{mM}$ aminobenzamide or $5.0 \mathrm{mM}$ nicotinamide. These results suggest that NAD depletion results from activation of the enzyme poly ADP-ribose polymerase but that NAD depletion does not account for the alterations in ATP metabolism.

Scavenger experiments. When endothelial cells were incubated with $25 \mathrm{mU} / \mathrm{ml}$ glucose oxidase and various oxygen radical scavengers, only catalase (scavenger of hydrogen peroxide) prevented DNA damage, whereas superoxide dismutase (scavenger of superoxide anion), dimethylsulfoxide (scavenger of hydroxyl radical), and deferoxamine (chelator of iron to prevent ironcatalyzed hydroxyl radical formation) did not prevent DNA damage (Fig. $3 A$ ). Similar results were obtained with endothelial cells exposed to $25 \mathrm{mU} / \mathrm{ml}$ xanthine oxidase and $5.0 \mathrm{mM}$ hypoxanthine for $60 \mathrm{~min}$ (Fig. $3 B$ ).

\section{DISCUSSION}

Recently, oxidant injury has been recognized to play a role in the pathophysiology of several diseases, including aging, carcinogenesis, oxygen toxicity, adult respiratory distress syndrome, reperfusion after ischemia, and immune-mediated diseases such as glomerulonephritis, rheumatoid arthritis, and vasculitis (1-3). In addition, several diseases of the premature newborn, including bronchopulmonary dysplasia, retinopathy of prematurity, necrotizing enterocolitis, and possibly intraventricular hemorrhage may be a result of oxidant injury (19). Successful antioxidant therapy in these diseases will depend upon a better understanding of the mechanisms of cellular injury after oxidant stress. 
Table 1. Comparison of ATP and NAD levels after oxidant injury when poly ADP-ribose polymerase is not inhibited and when inhibited with $5 \mathrm{mM}$ 3-aminobenzamide $(A B A)$ and $5 \mathrm{mM}$ nicotinamide $(N I C)^{*}$

\begin{tabular}{|c|c|c|c|c|c|c|}
\hline \multirow{2}{*}{$\begin{array}{l}\text { Oxidase } \\
(\mathrm{mU} / \mathrm{ml})\end{array}$} & \multicolumn{3}{|c|}{ ATP $\mathrm{pmol} / \mu \mathrm{g}$ protein } & \multicolumn{3}{|c|}{ NAD pmol $/ \mu \mathrm{g}$ protein } \\
\hline & 0 & $5 \mathrm{mM} \mathrm{ABA}$ & $5 \mathrm{mM}$ NIC & 0 & $5 \mathrm{mM}$ ABA & $5 \mathrm{mM} \mathrm{NIC}$ \\
\hline \multicolumn{7}{|l|}{ Glucose } \\
\hline 0 & $7.59 \pm 0.29$ & $6.29 \pm 0.61$ & $6.84 \pm 0.38$ & $2.64 \pm 0.10$ & $2.62 \pm 0.06$ & $2.61 \pm 0.17$ \\
\hline 10 & $6.42 \pm 0.51$ & $6.58 \pm 0.51$ & $5.28 \pm 0.43$ & $1.84 \pm 0.17$ & $2.90 \pm 0.04$ & $2.23 \pm 0.12$ \\
\hline 20 & $0.84 \pm 0.29$ & $2.90 \pm 0.34$ & $3.19 \pm 0.66$ & $0.36 \pm 0.05$ & $2.87 \pm 0.24$ & $2.08 \pm 0.06$ \\
\hline 30 & $0.13 \pm 0.11$ & $1.56 \pm 0.28$ & $1.43 \pm 0.30$ & $0.04 \pm 0.08$ & $2.29 \pm 0.11$ & $1.74 \pm 0.08$ \\
\hline 40 & $0.12 \pm 0.09$ & $0.63 \pm 0.12$ & $1.06 \pm 0.07$ & $0.06 \pm 0.04$ & $2.40 \pm 0.09$ & $1.34 \pm 0.08$ \\
\hline 50 & $0.08 \pm 0.09$ & $0.47 \pm 0.26$ & $0.70 \pm 0.26$ & $0.05 \pm 0.02$ & $2.54 \pm 0.13$ & $1.16 \pm 0.07$ \\
\hline \multicolumn{7}{|l|}{ Xanthine } \\
\hline 0 & $6.92 \pm 0.86$ & $5.79 \pm 0.48$ & $5.39 \pm 0.45$ & $1.69 \pm 0.08$ & $1.75 \pm 0.15$ & $1.76 \pm 0.17$ \\
\hline 10 & $6.11 \pm 1.13$ & $5.69 \pm 0.69$ & $5.00 \pm 0.89$ & $1.72 \pm 0.23$ & $1.79 \pm 0.15$ & $1.80 \pm 0.21$ \\
\hline 20 & $4.05 \pm 0.65$ & $3.35 \pm 0.51$ & $3.89 \pm 0.35$ & $1.60 \pm 0.11$ & $1.84 \pm 0.12$ & $1.88 \pm 0.03$ \\
\hline 30 & $1.76 \pm 0.21$ & $1.74 \pm 0.25$ & $1.73 \pm 0.14$ & $0.69 \pm 0.10$ & $1.50 \pm 0.07$ & $1.41 \pm 0.17$ \\
\hline 40 & $0.94 \pm 0.22$ & $1.16 \pm 0.13$ & $1.46 \pm 0.18$ & $0.55 \pm 0.01$ & $1.81 \pm 0.10$ & $1.30 \pm 0.08$ \\
\hline 50 & $0.71 \pm 0.08$ & $0.94 \pm 0.13$ & $1.17 \pm 0.39$ & $0.61 \pm 0.05$ & $1.93 \pm 0.15$ & $1.33 \pm 0.04$ \\
\hline
\end{tabular}

$*$ Values are mean of four replicates $\pm 1 \mathrm{SD}$.

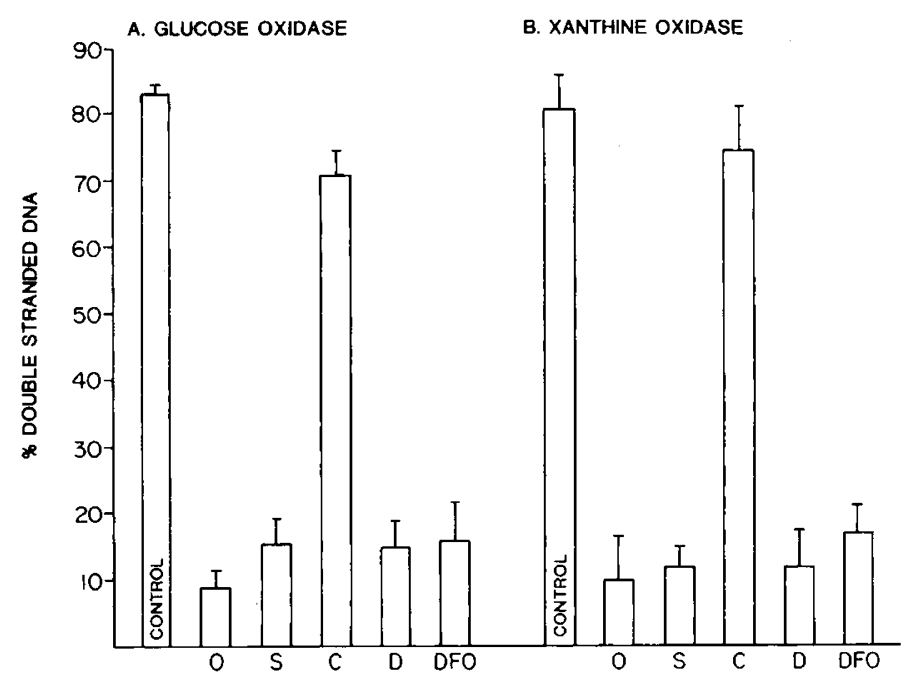

Fig. 3. Percentage of residual double-stranded DNA of endothelial cells exposed to $25 \mathrm{mU} / \mathrm{ml}$ glucose oxidase with $5.0 \mathrm{mM}$ glucose $(A)$ and $25 \mathrm{mU} / \mathrm{ml}$ xanthine oxidase with $5.0 \mathrm{mM}$ hypoxanthine $(B)$ with no scavenger $(0), 100 \mu \mathrm{g} / \mathrm{ml}$ superoxide dismutase $(S), 100 \mu \mathrm{g} / \mathrm{ml}$ catalase $(C), 0.1 \%$ dimethylsulfoxide $(D)$, or $75 \mu \mathrm{M}$ deferoxamine $(D F O)$. Values represent the mean of three replicates.

The precise mechanism(s) of cellular injury and metabolic alterations after oxidant injury are not well defined. In bovine endothelial cells, in the P388D1 cell line, and in lymphocytes, oxidant stress has been found to result in depletion of ATP (810). In the P3888D1 cell line and in lymphocytes, the mechanism of ATP depletion appears to result from activation of the enzyme poly ADP-ribose polymerase (11-13). Oxidant injury results in DNA damage $(20,21)$, which stimulates the DNA-repairing enzyme poly ADP-ribose polymerase to repair oxidant-induced DNA damage $(22,23)$. Once activated, poly ADP-ribose polymerase repairs DNA breaks by covalently attaching ADP-ribose moieties derived from NAD to nuclear proteins. Consumption of NAD via increased activity of poly ADP-ribose polymerase then interferes with ATP synthesis $(11,12)$. In lymphocytes and P388D1 cells, inhibition of poly ADP-ribose polymerase with nicotinamide or 3-aminobenzamide results in protection from NAD and ATP depletion and subsequent cell lysis (11-13, 23).

To investigate the mechanisms of ATP depletion in endothelial cells, a prime target of oxidant injury, we performed similar experiments with human umbilical vein endothelial cells. We found that oxidant injury resulted in extensive DNA damage and that NAD and ATP levels fell coincident with the DNA damage. Like lymphocytes and P388D1 cells, we found that inhibition of poly ADP-ribose polymerase with nicotinamide or 3 -aminobenzamide during oxidant stress protected the cell from NAD depletion. However, in contrast to the P388D1 cell line and lymphocytes, maintenance of NAD levels by inhibition of poly ADP-ribose polymerase did not protect the cell from ATP depletion. ATP depletion occurred despite maintenance of NAD levels.

To evaluate for other causes of the decline in ATP levels, we determined recovery of ATP exposed to glucose oxidase and xanthine oxidase in the absence of cells. The mechanism for the fall in intracellular ATP levels after oxidant injury was not the result of a direct interaction between hydrogen peroxide and ATP because recovery of ATP incubated with hydrogen peroxide generated by hypoxanthine-xanthine oxidase and glucose-glucose oxidase in the absence of cells was nearly $100 \%$. The decline in intracellular ATP levels was not due to efflux of ATP from a damaged cell membrane because ATP was not detectable in the cell supernatants. Thus, neither depletion of ATP via activation of poly ADP-ribose polymerase, release of ATP via cell membrane damage, nor direct degradation of ATP by reactive oxygen molecules accounts for the profound depletion of ATP in human endothelial cells after oxidant stress. Inhibition of glycolysis via oxidant-induced injury of glyceraldehyde 3-phosphate dehydrogenase or oxidant-induced alterations of essential sulfhydryl groups of glucose-6-phosphate dehydrogenase are additional mechanisms that may contribute to ATP depletion after oxidant stress in human cells $(12,24)$.

In previous studies, we and others have found that hydrogen peroxide was the reactive oxygen molecule responsible for injury after oxidant stress $(6,25,26)$. The addition of superoxide dismutase, a scavenger of superoxide anion, or mannitol, ethanol, and dimethylsulfoxide, each hydroxyl radical scavengers, did not prevent injury, whereas catalase, a scavenger of hydrogen peroxide, was effective. However, in cell-free systems, other studies have shown that hydroxyl radical derived from hydrogen peroxide mediates strand breaks $(20,27,28)$. In this study, we again found that catalase prevented DNA strand breaks, whereas scavengers of superoxide anion or hydroxyl radical did not. Although the hydroxyl radical scavengers did not prevent the DNA damage, it is likely that hydroxyl radical derived from hydrogen peroxide within the cell resulted in strand breaks and that the extracellular scavengers were inaccessible at the intracellular site of hydroxyl radical generation. Because the reactive oxygen molecules were generated extracellularly and 
because catalase was added to the extracellular environment, presumably catalase scavenged the hydrogen peroxide extracellularly before entry into the cell.

In conclusion, we report that oxidant injury to human umbilical vein endothelial cells results in profound DNA damage and in NAD and ATP depletion. NAD depletion results from activation of the DNA-repairing enzyme poly ADP-ribose polymerase. In contrast, ATP depletion is not a result of activation of poly ADP-ribose polymerase and NAD depletion.

Acknowledgments. We thank Mrs. Carol Teets for preparing the manuscript, the nursing and obstetrical staff at St. Vincent's Hospital, Indianapolis, IN, for collecting umbilical cords, and Mrs. Collen Mallett for technical assistance.

\section{REFERENCES}

1. Cross CE, Halliwell B, Borish ET, Pryor WA, Ames BN, Saul RL, McCord JM, Harman D 1987 Oxygen radicals and human disease. Ann Intern Med 107:506-545

2. Southorn PA, Powis G 1988 Free radicals in medicine II involvement in human disease. Mayo Clin Proc 63:390-408

3. Halliwell B 1987 Oxidant and human disease: some new concepts. FASEB J $1: 358-364$

4. Freeman BA, Crapo JD 1982 Free radicals and tissue injury. Lab Invest 47:412-426

5. Harlan JM, Levine JD, Callahan KS, Schwartz BR 1984 Glutathione redox cycle protects cultured endothelial cells against lysis by extracellularly generated hydrogen peroxide. J Clin Invest 73:706-713

6. Andreoli SP, Mallett CH, Bergstein JM 1986 Role of glutathione in protecting endothelial cells against hydrogen peroxide oxidant injury. $J$ Lab Clin Med 108:190-198

7. Hyslop PA, Hinshaw DB, Schraufstatter IU, Sklar LA, Spragg RG, Cochrane CG 1986 Intracellular calcium homoeostasis during hydrogen peroxide oxidant injury to cultured P388D1 cells. J Cell Physiol 129:356-366

8. Spragg RG, Hinshaw BO, Hyslap PA, Schraufstatler IU, Cochrane GG 1985 Alterations in adenosine triphosphate energy charge in cultured endothelial and P388D1 cells after oxidant injury. J Clin Invest 76: 1471-1476

9. Carson DA, S Seto, DB Wasson 1986 Lymphocyte dysfunction after DNA damage by toxic oxygen species. J Exp Med 163;746-751

10. Schraufstatter IU, Hinshaw DB, Hyslop PA, Spragg RG, Cochrane CG 1986 Oxidant injury of cells: DNA strand-breaks activate poly adenosine diphosphate-ribose polymerase and lead to depletion of nicotinamide adenine dinucleotide. J Clin Invest 77:1312-1320
11. Carson DA, Seto S, Wasson DB, Carrera CJ 1986 DNA strandbreaks, NAD metabolism and programmed cell death. Exp Cell Res 164:273-281

12. Schraufstatter IU, Hyslop PA, Hinshaw DB, Spragg RG, Sklar LA, Cochrane CG 1986 Hydrogen peroxide-induced injury of cells and its prevention by inhibitors of poly (ADP-ribose) polymerase. Proc Natl Acad Sci USA 83:4908-4912

13. Jarasch ED, Bruder G, Heid HW 1986 Significance of xanthine oxidase in capillary endothelial cells. Acta Physiol Scand 548:39-46

14. Birnboim HC, Jevcak JJ 1981 Fluorometric method for rapid detection of DNA strand breaks in human white blood cells produced by low doses of irradiation. Cancer Res 41:1889-1892

15. Lorenzi M, Montisano DF, Toledo S, Barrieux A 1986 High glucose induces DNA damage in cultured human endothelial cells. J Clin Invest 77:322-325

16. Stanley PE, William SG 1969 Use of the liquid scintillation spectrometer for determining adenosine triphosphate by the luciferase enzyme. Anal Biochem 29:381-392

17. Lowry OH, NHJ Rosebrough, AL Farr, RJ Randall 1951 Protein measurement with the Folin phenol reagent. J Biol Chem 193:265-275

18. Bernofsky C, Swan M 1973 Am improved cycling assay for nicotinanide adenine dinucleotide. Analytical Biochem 53:452-458

19. Saugstad OD 1988 Hypoxanthine as an indicator of hypoxia: its role in health and disease through free radical production. Pediatr Res 23:143-150

20. Brawn K, Fridovich I 1981 DNA strand scission by enzymically generated oxygen radicals. Arch Biochem Biophy 206:414-419

21. Hoffman ME, Filho AC, Meneghini R 1984 Correlation between cytotoxic effect of $\mathrm{H}_{2} \mathrm{O}_{2}$ and the yield of DNA strand breaks in cells of different species. Biochem Biophys Acta 781:234-238

22. Berger NA, Shikorski GW, Petzola SJ, Kuorhara KK 1979 Association of poly (adenosine diphosphoribose) synthesis with DNA damage and repair in normal human lymphocytes. J Clin Invest 63:1164-1171

23. Berger NA 1985 Poly (ADP-ribose) in the cellular response to DNA damage. Rad Res 101:4-15

24. Delucia AJ, Hoque PM, Mustafa MG, Cross CE 1972 Ozone interaction with rodent lung: effect on sulfhydryls and sulfhydryl-containing enzyme activities. J Lab Clin Med 80:559-566

25. Weiss SJ, Young J, LoBuglio AF, Slivka A, Mineh NF 1981 Role of hydrogen peroxide in neutrophil-mediated destruction of cultured endothelial cells. J Clin Invest 68:714-721

26. Martin WJ 1984 Neutrophils kill pulmonary endothelial cells by a hydrogen peroxide dependent pathway: an in vitro model of neutrophil mediated lung injury. Am Rev Respir Dis 130:209-213

27. Bradley MO, Erickson LC 1981 Comparison of the effects of hydrogen peroxide and $x$-ray irradiation on toxicity, mutation, and DNA damage/repair in mammalian cells (V-79). Biochem Biophys Acta 654:135-141

28. Lesko SA, Drocourt JL, Yang SU 1982 Deoxyribonucleic acid-protein and deoxyribonucleic acid interstrand cross-links induced in isolated chromatin by hydrogen peroxide and ferrous ethylenediaminetetraacetate chelates. Biochem 21:5010-5015 